\title{
PRINSIP MENGENAL NASABAH (KNOW YOUR CUSTOMER PRINCIPLE) OLEH PENYEDIA JASA KEUANGAN DI BIDANG PASAR MODAL
}

\author{
Oleh : ALIS YULIA*) \\ (alisyulia 68@yahoo.com)
}

\begin{abstract}
The principle of getting to know customers is a principle applied by banks to know Customer Identity, monitor customer transaction activities including reporting suspicious transactions. All banks should create effective procedures in obtaining the correct identity of new customers, as well as activities in the capital market should also make stricter procedures for prospective customers in the process of buying and selling shares and Bapepam as a supervisory institution in the capital market has the right to have the authority to knowing the issuers are also investors who make securities buying and selling transactions. Brokers or brokers and also eek traders are obliged to ensure that their business activities are carried out, it is recommended that they have good intentions with high ethics so that all legislation can be implemented properly.
\end{abstract}

Keywords : Customer Principles, Financial Markets, Capital Markets.

\begin{abstract}
Abstrak
Prinsip mengenal nasabah merupakan prinsip yang diterapkan bank untuk mengetahui Identitas Nasabah, memantau kegiatan transaksi nasabah termasuk pelaporan transaksi yang mencurigakan. Semua bank sebaiknya menciptakan prosedur yang efektif dalam memperoleh identitas yang benar atas nasabah baru, begitu pula dengan kegiatan di pasar modal juga sebaiknya membuat prosedur yang lebih ketat terhadap calon nasabah dalam proses jual beli saham dan Bapepam sebagai lembaga pengawas dalam pasar modal berhak memiliki kewenangan untuk mengetahui emiten juga investor yang melakukan transaksi jual beli efek. Pialang atau broker dan juga pedagang eek wajib untuk menjamin bahwa kegiatan bisnis mereka laksanakan disarankan harus mempunyai itikad baik dengan etika yang tinggi sehingga semua peraturan Perundang-undangan dapat dilaksanakan dengan baik.
\end{abstract}

Kata Kunci : Prinsip Nasabah, Pasar Keuangan, Pasar Modal.

\section{LATAR BELAKANG}

Bank sebagai lembaga keuangan dalam menjalankan usahanya menghadapi berbagai risiko sejalan dengan perkembangan teknologi dan globalisasi, dewasa ini sektor perbankan telah menjadi sarana yang paling efektif untuk kegiatan pencucian

\footnotetext{
*) Dosen Tetap Fakultas Hukum Universitas Galuh
} 
uang (money laundering), hal ini dikarenakan faktor perbankan banyak menawarkan jasa-jasa dan instrument dalam lalu lintas keuangan yang dapat digunakan untuk menyembunyikan / menyamarkan asal usul dana.

Pesatnya pertumbuhan Perbankan di Indonesia dewasa ini memicu bank untuk beroperasi dalam iklim usaha yang begitu kompetitif, ketatnya persaingan di bidang usaha perbankan membuat pengelola usaha bank berupaya secara maksimal agar setiap kegiatan dilakukan secara efisien dan efektif, sehingga tidak dihindarkan adanya pemakaian alat-alat elektronik seperti Automatic Teller Machine (ATM), Electronic Fund Transfer (EFT) dan Internet Banking. Adanya fasilitas perbankan modern tersebut mengakibatkan usaha bank menghadapi resiko yang sangat tinggi.

Beberapa kemudahan yang ditawarkan untuk bertransaksi di dalam pasar modal menjadi celah bagi para pelaku tindak pidana untuk menjalankan aksi kejahatan melalui scripless trading atau pedagang elektronik (tanpa warkat), terjadilah tindak pidana pencucian uang, apabila nasabah yang melakukan transaksi tidak dilakukan legal due diligence, sehingga terhadap peningkatan tindak pidana di bidang transaksi dalam pasar modal, contohnya tindak pidana pencucian uang. Oleh karenanya diterapkan prinsip mengenal nasabah yang sebelumnya diterapkan pada bank, diterapkan juga pada pasar modal untuk mencegah kejahatan dalam pasar modal.

Berdasarkan hal tersebut, Pasar Keuangan dan Pasar Modal perlu berhatihati dalam bertransaksi bisnis, maka dari itu berdasarkan Pasal 1 huruf $(k)$ keputusan Ketua Badan Pengawas Pasar Modal dan lembaga keuangan Nomor : KEP476/BL/2009 tanggal 01 Januari 2010 prinsip mengenal nasabah (know your customer principle) oleh penyedia Jasa Keuangan di Bidang Pasar Modal yaitu "Prinsip Mengenal Nasabah adalah prinsip yang diterapkan Penyedia Jasa Keuangan di bidang Pasar Modal, untuk mengetahui latar belakang dan identitas Nasabah memantau rekening efek, serta melaporkan transaksi keuangan yang mencurigakan, dan transaksi keuangan yang dilakukan secara tunai sesuai dengan Peraturan Perundang-undangan yang terkait dengan tindak pidana pencucian uang, termasuk transaksi keuangan yang terkait dengan Pendanaan Kegiatan Terorisme.

Berdasarkan pengertian prinsip mengenal nasabah pada Keputusan Ketua Badan Pengawas Pasar Modal dan Lembaga Keuangan, terdapat unsur-unsur yaitu : 
a. Mengetahui latar belakang dan identitas nasabah, yang dilakukan dengan cara legal due diligence, yaitu diperiksa mengenai latar belakang nasabah secara keseluruhan, dan dilakukan oleh konsultan hukum.

b. Memantau rekening efek dan transaksi nasabah. Pemantauan rekening efek dan transaksi nasabah ini harus dilakukan kerjasama antara konsultan keuangan (akuntan) dan konsultan hukum. Peran dari konsultan keuangan adalah memeriksa rekening efek dan transaksi keuangan dari para nasabah dipantau arus masuk keluarnya (in and out flow). Apakah transaksi di atas terdapat hal-hal yang mencurigakan bila terdapat transaksi yang terindikasi melakukan kecurangan atau kejahatan yang berupa kejahatan money laundering, insider trading. Dalam hal ini konsultan hukum bertugas memeriksa transaksi-transaksi yang mencurigakan tersebut, apakah memenuhi unsur pidana atau tidak. Apakah transaksi tersebut dapat menjadi sebuah tindak kejahatan baik secara langsung maupun tidak langsung.

Dalam prinsip mengenal nasabah di Pasar Modal dengan prinsip mengenal nasabah pada Pasar Keuangan, adalah sebagai berikut :

a. Bank dan Pasar Modal keduanya merupakan lembaga keuangan yang sangat berisiko digunakan sebagai media dalam berbagai tindak kejahatan.

b. Fungsi dari pasar keuangan dan pasar modal sebagai lembaga keuangan yang menghimpun dana dalam masyarakat sehingga baik pelaku bisnis yang berada di lembaga keuangan dan pasar modal keduanya berupaya untuk melakukan pertumbuhan bisnis dengan berbagai upaya yang tidak memberatkan atau memberikan kenyamanan bagi pihak nasabahnya.

c. Modus kejahatan baik yang dilakukan di pasar keuangan maupun di pasar modal umumnya, karakteristik kejahatan tersebut hampir serupa.

d. Terdapat pengaturan untuk transaksi baik di pasar keuangan maupun pasar modal harus menerapkan prinsip mengenal nasabah untuk mengetahui profil dari nasabah tersebut.

e. Terdapat adanya sanksi, baik di pasar keuangan maupun pasar modal yang tidak taat terhadap ketentuan yang mengatur tentang prinsip mengenal nasabah.

Berdasarkan uraian pada latar belakang permasalahan yang telah dikemukakan di atas, maka permasalahan yang dibahas dapat dirumuskan dalam pertanyaan sebagai berikut : 
1. Bagaimanakah pelaksanaan prinsip mengenal nasabah (know your customer principle) oleh penyedia Jasa Keuangan di bidang Pasar Modal ?

2. Hambatan dalam pelaksanaan prinsip mengenal nasabah (know your customer principle) oleh penyedia Jasa Keuangan di bidang Pasar Modal ?

\section{TINJAUAN PUSTAKA}

\subsection{Definisi Prinsip Mengenal Nasabah}

Definisi Prinsip mengenal nasabah (know your customer principle) sebagai prinsip yang diterapkan oleh Bank untuk mengetahui secara mendalam identitas nasabah dan memantau kegiatan transaksi nasabah termasuk kegiatan pelaporan pada transaksi yang mencurigakan. Penerapan prinsip mengenal nasabah ini meliputi baik nasabah bank biasa (face to face customer) maupun nasabah tanpa berhadapan (non face to face customer), seperti nasabah yang melakukan transaksi melalui telepon, surat menyurat, electronik banking (Munir Fuady, 2004 : 210).

Prinsip mengenal nasabah merupakan prinsip yang diterapkan bank untuk mengetahui identitas nasabah termasuk pelaporan transaksi yang mencurigakan. Sejalan dengan tuntutan dan kebutuhan untuk melakukan penyesuaian terhadap standar internasional sebagaimana direkomendasikan oleh Bank of International Settlement, Basel Comitee Bank Indonesia yang mengeluarkan peraturan tentang prinsip mengenal nasabah (know your customer principle). (Tarsisius Muwaji, $2004: 53)$.

Dalam memantau transaksi yang mencurigakan ini juga berdasarkan amanat dalam Keputusan Ketua Badan Pengawas Pasar Modal dan Lembaga Keuangan Nomor KEP-476/BL/2009 tentang Prinsip Mengenal Nasabah oleh Penyedia Jasa Keuangan di Bidang Pasar Modal. Hal ini disebabkan terjadinya tindak pidana yang sama dalam bank dan Pasar Modal yang sama-sama sebagai lembaga keuangan. Lembaga yang membuat peraturan dalam pasar modal, adalah Badan Pengawas Pasar Modal Lembaga Pengawas dalam Pasar Modal berhak dan memiliki kewenangan untuk mengetahui setiap pihak yang melakukan transaksi dan juga pihak yang berhubungan dengan Pasar Modal. 


\subsection{Data Yang Diperlukan Dalam Rangka Mengenal Nasabah Oleh Penyedia Jasa Keuangan di Pasar Modal}

Dalam rangka menegakan prinsip mengenal nasabah Bank Indonesia atau Lembaga Keuangan lainnya dalam hal ini adalah Pasar Modal diwajibkan untuk memperoleh data tertentu dan nasabah sebagai berikut :

a. Data Informatif.

b. Dokumen pendukung terhadap data informatif.

c. Jika telah menggunakan media elektronik, melakukan pertemuan tatap muka sekurang-kurangnya pada saat pembukaan rekening.

d. Melakukan wawancara dengan nasabah untuk meneliti keabsahan dan kebenaran dokumen.

Untuk kegiatan dari pihak-pihak yang berhubungan dengan pasar modal sehubungan dengan prinsip mengenal nasabah harus memenuhi persyaratan sama halnya dengan kegiatan perbankan, tetapi untuk kegiatan pasar modal diperlukan pembukaan rekening efek.

Mengenai data normatif yang diperlukan, wajib diketahui oleh bank dan harus dibuktikan dengan dokumen-dokumen pendukungnya, di samping itu bank wajib pula meneliti kebenaran dokumen pendukung identitas calon nasabah. Hal ini serupa juga dengan prinsip mengenai nasabah pada pasar modal, data informatif tersebut adalah :

a. Identitas Calon Nasabah

b. Maksud dan tujuan hubungan usaha yang akan dilakukan calon nasabah dengan bank.

c. Informasi lain yang memungkinkan bank untuk mengetahui Profil Calon Nasabah.

d. Identitas pihak lain dalam hal nasabah bertindak untuk dan atas nama pihak lain.

Di sini Bapepam sebagai lembaga Pengawas dalam pasar modal berhak dan memiliki kewenangan untuk mengetahui setiap pihak yang melakukan transaksi dan juga pihak-pihak yang berhubungan dengan Pasar Modal.

\subsection{Pengertian Nasabah Sebagai Perantara/ Kuasa}

Diperlukan perhatian khusus jika ternyata Nasabah hanyalah merupakan perantara atau kuasa dari pihak lain (beneficial owner), beberapa ketentuan yang berlaku bagi nasabah tersebut adalah sebagai berikut :

a. Bank wajib memperoleh data dan informasi tentang identitas nasabah perantara. 
b. Bank wajib memperoleh bukti atas pihak beneficial owner berupa :

1) Sumber dana

2) Tujuan penggunaan dana

3) Bukti pemberian kuasa kepada calon nasabah.

4) Pernyataan dari calon nasabah bahwa telah dilakukan penelitian terhadap kebenaran identitas maupun sumber dari pihak benefical owner.

Definisi Bapepam sebagai lembaga pengawas dalam pasar modal berhak dan memiliki kewenangan untuk mengetahui setiap hak yang melakukan transaksi dan juga pihak-pihak yang berhubungan dengan Pasar Modal.

\section{PEMBAHASAN}

\subsection{Prinsip Mengenal Nasabah}

Prinsip mengenal nasabah merupakan sarana yang paling efektif bagi perbankan untuk menanggulangi kejahatan pencucian uang, demikian juga dengan kegiatan di pasar modal yang berdampak terhadap penilaian masyarakat, nasabah atau mitra transaksi bank terhadap bank yang bersangkutan, yaitu risiko operasional (operational risk) dan resiko reputasi (reputation risk) (N.H.T. Siahaan, 2002 : 74).

Risiko operasional (operational risk) merupakan risiko di mana pialang atau broker dan juga pedagang efek tidak dapat melakukan operasionalnya secara normal, karena ada kesalahan dan penyalahgunaan wewenang ketidakpastian terhadap ketentuan, kelemahan struktur pengendalian (intern), prosedur yang tidak memadai, gangguan sistem informasi manajemen dan komunikasi, gangguan sistem pembayaran transaksi jual beli efek. Kebanyakan risiko operasional dalam kaitannya dengan prinsip mengenal nasabah terkait dengan kelemahan-kelemahan dalam implementasi program-program pialang, broker dan juga pedagang efek, prosedur pengawasan yang tidak efektif dan tidak dilaksanakannya due deligence oleh bank tersebut.

Risiko Reputasi (reputation risk) merupakan suatu risiko yang menimbulkan menurunnya atau hilangnya reputasi Pialang atau broker dan juga pedagang efek di mata publik atau pemerintah.

Risiko hukum (legal risk) terjadi dikarenakan Pialang atau broker dan juga pedang efek kurang memperhatikan aspek-aspek yuridis dari perjanjian atau hal-hal yang beraspek kontraktual, pialang atau broker dan juga pedagang efek dapat menjadi sasaran gugatan sebagai akibat tidak dipatuhinya prinsip mengenal nasabah 
yang diwajibkan, misalnya dijatuhi denda, harus bertanggung jawab secara pidana, dan dijatuhi berbagai sanksi yang dijatuhkan oleh Bapepam.

Risiko konsentrasi (consentration risk) terjadi karena pialang atau broker dan juga pedagang efek menerima dana-dana dari pihak ketiga dalam jumlah yang besar yang terkonsentrasi terhadap beberapa emiten atau investor. Pada sisi liabilitas pada neraca keuangan, Pialang atau broker dan juga pedagang efek, risiko konsentrasi terkait erat dengan risiko yang berupa penjualan atau pembelian efek secara seketika sehingga berpotensi menjadi transaksi yang mencurigakan. Terjadinya funding risk besar sekali kemungkinannya, dalam hal pialang atau broker, pedagang efek kecil yang kurang aktif di bursa efek dibanding pialang atau broker dan juga pedagang efek yang besar, hendaklah pialang atau broker, pedagang efek paham karakteristik dari emiten dan perusahaan yang melakukan proses jual beli, termasuk tidak hanya identitas dari nasabah tersebut, tetapi juga sejauhmana kegiatan nasabah tersebut yang terkait dengan nasabah lainnya.

\subsection{Pemantauan Rekening Nasabah}

Dalam rangka melaksanakan program kenal nasabah ini, Bapepam harus mempunyai sistem yang baik terhadap pemantauan rekening nasabah, dalam hal ini Bank wajib melakukan hal-hal sebagai berikut :

a. Melakukan upgrade data sehingga sesuai dengan keadaan saat terakhir.

b. Menatausahakan dokumen nasabah selalu lima tahun sejak nasabah menutup rekeningnya.

c. Memiliki sistem informasi mengenai karakteristik transaksi nasabah.

d. Memelihara profil nasabah yang sekurang-kurangnya meliputi :

1) Bidang usaha atau pekerjaan

2) Penghasilan

3) Rekening lain yang dimiliki

4) Aktivitas transkasi yang normal

5) Tujuan pembukaan rekening

\subsection{Kewajiban Pelaporan Oleh Penyedia Jasa Keuangan}

Bank wajib menyampaikan kepada Bank Indonesia mengenai kebijakan dan prosedur program kenal nasabah, di samping itu bank wajib pula melaporkan kepada Bank Indonesia apabila terjadi transaksi yang mencurigakan (suspicious transaction) 
dalam waktu selambat-lambatnya tujuh hari kerja setelah diketahui oleh Bank sesuai format yang telah ditentukan oleh Bank Indonesia. Dalam hal Pasar Modal maka Bapepam melakukan pelaporan kepada Bursa Efek agar dilakukan pembekuan aktivitas transaksi dari nasabah yang memiliki transaksi yang mencurigakan.

Berbagai bentuk pelaporan yang harus dilakukan adalah :

a. Pelaporan tentang Penerapan Prinsip Mengenal Nasabah yang telah disesuaikan dengan ketentuan sebagaimana dimaksud dalam angka 3 huruf b Peraturan Nomor V.D.10 Lampiran Keputusan ini paling lambat tanggal 30 Juni 2010.

b. Pelaporan tentang pengkinian data terhadap nasabah sebagaimana dimaksud dalam angka 11 huruf $\mathrm{c}, \mathrm{d}$ huruf $\mathrm{g}$, dan huruf $\mathrm{h}$ Peraturan Nomor V.D.10.

\subsection{Sanksi-sanksi}

Bagi Bank yang lalai dalam melakukan tugasnya dalam rangka program kenal nasabah akan dikenakan sanksi administrasi sebagaimana dimaksud dalam Undang-undang Republik Indonesia Nomor 10 Tahun 1998 tentang Perbankan, selain itu apabila cukup bukti bahwa telah terjadi kejahatan money laundering, si pelakunya dapat diproses pidana sesuai aturan yang berlaku, sementara di dalam Keputusan Ketua Badan Pengawas Pasar Modal dan Lembaga Keuangan Nomor KEP.476/BL/2009 tentang Prinsip Mengenal Nasabah oleh Penyedia Jasa Keuangan di Bidang Pasar Modal tidak diatur mengenai sanksi apabila pedagang efek atau peraturan dagang efek atau perantara pedagang efek pada bank tidak menjalankan prinsip mengenal nasabah, sanksi administrasinya adalah :

a. pencabutan izin

b. denda uang

c. teguran tertulis

d. penurunan tingkat kesehatan bank

e. larangan untuk turut serta dalam kegiatan kliring

f. pembekuan kegiatan usaha tertentu, baik untuk Kantor Cabang tertentu maupun untuk Bank secara keseluruhan

g. pemberhentian pengurus bank selanjutnya menunjuk dan mengangkat pengganti sementara sampai Rapat Umum Pemegang Saham mengangkat pengganti yang tetap dengan persetujuan Bank Indonesia. 
h. pencantuman anggota, pengurus, pegawai bank, pemegang saham dalam daftar orang tercela di bidang perbankan.

\section{KESIMPULAN}

1. Penyedia Jasa Keuangan di bidang pasar modal wajib melakukan verifikasi yang lebih ketat (enchanced due deligence) terhadap calon nasabah dan pengendali calon nasabah yang dianggap mempunyai resiko tinggi. Tingkat risiko tersebut dapat dilihat dari :

a. Latar belakang atau profil nasabah, orang populer secara politis (politically exposed person) atau nasabah yang beresiko tinggi (high risk costumer).

b. Bidang usaha calon nasabah yang termasuk usaha yang berisiko tinggi (high risk business).

2. Penyedia Jasa Keuangan di bidang Pasar Modal dilarang untuk membantu atau memelihara rekening efek anonim atau rekening efek yang menggunakan nama fiktif.

3. Pembukaan rekening efek hubungan usaha dengan calon nasabah yang dianggap atau diklasifikasikan mempunyai resiko tinggi wajib terlebih dahulu memperoleh persetujuan dari anggota direksi atau manajemen senior Penyedia Jasa Keuangan di Bidang Pasar Modal.

Persetujuan pembukaan rekening efek atau hubungan usaha dapat diberikan setelah meyakini kebenaran identitas dan kelengkapan dokumen Calon Nasabah serta mempertimbangkan faktor-faktor yang dapat memungkinkan nasabah melakukan kegiatan pencucian uang antara lain catatan, dokumen, daftar, informasi mengenai pelanggaran/kejahatan. 


\section{DAFTAR PUSTAKA}

Leden Marpaung, Kejahatan Terhadap Perbankan, Erlangga, Jakarta, 1993.

Munir Fuady, Hukum Perbankan Modern, Citra Aditya Bankti, Bandung, 2004.

Pasar Modal Modern (Tinjauan Hukum), PT. Citra Aditya Bakti, Bandung, 1996.

NHT, Siahaan, Pencucian Uang dan Kejahatan Perbankan, CV, Mulia Sari, Jakarta, 2002.

Sumantoro, Aspek-aspek Hukum dan Potensi Pasar Modal di Indonesia, Ghalia Indonesia, Jakarta, 1987.

\section{Peraturan Perundang-undangan :}

Keputusan Ketua Badan Pengawas Pasar Modal dan Lembaga Keuangan Nomor : KEP-476/BL/2009 tentang Prinsip Mengenal Nasabah Oleh Penyedia Jasa Keuangan di Bidang Pasar Modal. 